\title{
UPAYA MENINGKATAN HASIL BELAJAR SISWA DENGAN MENGGUNAKAN MODEL PEMBELAJARAN SNOWBALL THROWING
}

\author{
Nada Naviana Simarmata \\ Program Studi Pendidikan Guru Sekolah Dasar, Fakultas Keguruan dan Ilmu Pendidikan \\ Universitas Kristen Satya Wacana Salatiga, Indonesia \\ Email: 292015091@student.uksw.edu
}

\begin{abstract}
ABSTRAK
Penelitian ini merupakan penelitian metaanalisis yang bertujuan untuk meningkatkan hasil belajar siswa pada semua mata pelajaran dengan menggunakan model pembelajaran. Jenis penelitiaan ini adalah Penelitian Tindakan kelas. Tetapi artikel ini tidak melakukan eksperimen langsung hanya saja mengambil hasil penelitian dari orang lain. Dimana penelitian ini mencari 10 penelitian dan apakah menggunakan model pembelajaran Snowball Throwing berhasil atau tidak. Artikel yang menyatakan bahwa dengan menggunakan model pembelajaran Snowball Throwing ini ada di Undiksha, Unnes, UNM. Hasil penelitian ini menemukan bahwa model pembelajaran Snowball Throwing dapat meningkatkan hasil belajar siswa dan dapat membuat peserta didik aktif dalam proses belajar mengajar dilaksanakan dua siklus. Dalam penelitian ini terdapat 10 penelitian yang berhasil meningkatkan hasil belajar yang optimal.
\end{abstract}

Kata kunci :Hasil Belajar, Snowball Throwing, Hasil, Pembelajaran

\begin{abstract}
ABSTRACK
This research is a metaanalysis research that aims to improve student learning outcomes in all subjects by using learning model. Most teachers do not use learning models that fit the characteristics of students. So that learners are not active in the learning process of teaching, teachers only lectures and learners to listen it is what makes passive learners. Therefore, using the Snowball Throwing learning model of this research can improve student learning outcomes and can make active learners in the learning process implemented two cycles. In this study there are 10 researches that successfully improve the optimal learning outcomes.
\end{abstract}

Keywords : Learning Outcomes, Snowball Throwing, Results, Learning

\section{PENDAHULUAN}

Pendidikan sangatlah penting dalam kehidupan berbangsa dan bernegara untuk menjamin kelangsungan kehidupan dan perkembangan bangsa Indonesia. Menurut Undang-Undang Nomor 20 tahun 2003 pendidikan adalah usaha sadar dan yang terencana untuk mewujudkan suasana belajar dan proses belajar mengajar untuk dapat mengembangkan potensi yang dimiliki baik dalam spiritual, pengendalian diri, kepribadian, kecerdasan, akhlak mulia, serta keterampilan yang diperlukan oleh peserta didiknya, masyarakat bangsa dan Negara. Pendidikan itu sendiri harus dilandaskan empat pilar yaitu siswa mempelajari pengetahuan, menggunakan pengetahuan dengan mengembangkan keterampilan, siswa belajar menggunakan pengetahuan dan keterampilan yang hidup, siswa dapat belajar bahwa adanya saling ketergantungan sehingga diperlukan saling menghargai antar sesama

Guru disini hanya menjadi fasilitator saja dan memiliki kemampuan dalam 
memilih suatu pendekatan, model, metode, dan strategi yang akan digunakan sesuai dengan karakteristik siswa. Tetapi kenyataannya suatu pembelajaran ini masih saja guru tidak memperhatikan kesesuaian model yang akan digunakan dalam proses belajar mengajar dan guru tersebut kurang kreatif, sehingga menimbulkan kebosanan dalam pembelajaran.

Oleh karena itu, guru harus menciptakan model pembelajaran yang menyenangkan bagi peserta didik dan sesuai dengan kemampuan yang dimilikinya. Dengan menggunakan model pembelajaran Snowball Throwing dimana menggunakan model ini proses belajar mengajar menjadi menyenangkan karena siswa melempar bola kepada siswa, jadi setiap siswa akan mendapatkan kesempatan untuk memberikan soal dan dijawab oleh ke siswa lain. Model pembelajaran ini menjadikan siswa yang aktif, guru tidak perlu repotrepot membuat media pembelajaran.

Menurut Ismail, (2008:27) Snowball Throwing berasal dari dua kata yaitu "snowball" "throwing". Kata snowball berarti bola salju, sedangkan throwing berarti melempar, jadi Snowball Throwing adalah melempar bola salju. Pembelajaran Snowball Throwing merupakan salah satu model dari pembelajaran kooperatif. Pembelajaran Snowball Throwing merupakan model pembelajaran siswa dibagi menjadi beberapa kelompok, dan dimana setiap anggota kelompok membuat pertanyaan lalu dilemparkan ke siswa lainnya pertanyaan yang ditulis dikertas di bentuk seperti bola.Guru membentuk siswa menjadi beberapa kelompok secara acak atau heterogen.

Penelitian ini sangatlah penting bagi guru yang tidak memperhatikan model pembelajaran yang sesuai dengan karakteristik siswa khususnya yang ada di Jawa Tengah. Tujuan dari penelitian ini yaitu untuk meningkatkan hasil belajar siswa dengan menggunakan model pembelajaran Snowball Throwing, untuk membantu guru dalam mengatasi siswa yang pasif dan dapat memilih model pembelajaran yang menarik agar meningkatkan hasil belajar siswa, meningkatkan proses belajar mengajar di sekolah.

Menurut Sudjana (2005) mengatakan bahwa hasil belajar adalah belajar dan mengajar sebagai suatu proses yang mengandung tiga unsur yang dapat dibedakan, yakni tujuan pengajaran (instruksional), pengalaman (proses) belajar mengajar, dan hasil belajar. Jadi hasil belajar adalah suatu hasil yang akan dicapai oleh peserta didiknya baik dalam menguasai kecakapan jasmani dan rohani disekolah yang akan diwujudkan dalam bentuk rapot pada setiap semester. Supaya guru mengetahui perkembangan hasil belajar peserta didik, maka harus dilakukan evaluasi dan untuk menentukan kemajuan yang akan dicapai maka guru harus membuat kriteria atau patokan yang akan mengacu pada tujuan yang akan dicapai sehingga dapat mengetahui seberap besar pengaruh model pembelajaran yang sudah ditentukan untuk peserta didik.

Model pembelajaran Snowball Throwing dapat menciptakan suasana yang menyenangkan dalam suatu proses belajar mengajar dan dapat membangkitkan motivasi siswa dalam belajar. Dengan adanya model pembelajaran ini siswa dapat mudah memahami konsep-konsep maupun ide-ide yang lebih banyak dan lebih baik untuk memberikan informasi pengetahuan. Model pembelajaran ini dapat membatu siswa belajar mematuhi peraturan, membuat pertanyaan, menunggu giliran, memjawab pertanyaan dan belajar untuk menyesuaikan diri dalam satu kelompok. Snowball Throwing sebagai solusi dari permasalahan yang ada karena dengan menggunakan model pembelajaran ini dilakukan dengan cara berdiskusi secara berkelompok, sehingga peserta didik dapat aktif dan dapat bekerja sama dengan siswa lainnya, mereka juga belajar untuk membuat pertanyaan, menjawab pertanyaan, menunggu giliran dan saling memberikan informasi antar sesama teman.

Dengan menggunakan model pembelajaran Snowball Throwing guru dapat meningkatkan kepercayaan diri peserta didik dalam menyampaikan pendapatnya. Karena 
teknik yang digunakan diskusi ketua kelompok mendapatkan tugas dari guru, kemudian peserta didik masing-masing membuat pertanyaan yang dibentuk seperti bola yang nantinya akan dilemparkan ke peserta didik yang lain untuk mejawab pertanyaan tersebut.

\section{Langkah-langkah}

model

pembelajaran Snowball Throwing yaitu: (1) Guru menyampaikan materi yang akan disajikan. Setelah itu, guru membagikan siswa dalam kelompok, dan guru memanggil ketua kelompok yang sudah ditunjuk oleh kelompoknya dimana guru akan memberikan materi. (2) Ketua kelompok kembali kekelompok masing untuk menjelaskan materi yang sudah disampaikan oleh guru. (3) Setiap kelompok akan dibagikan lembar kerja siswa digunakan untuk menuliskan pertanyaan yang menyangkut dengan materi yang di jelaskan oleh ketua kelas. (4) Setelah siswa menuliskan pertanyaan di kertas, kemudian kertas tersebut di buat seperti bola yang nantinya akan di lemparkan kesalah satu siswa lain kurang lebih 5 menit. (5) Siswa akan mendapatkan satu bola yang berisikan pertanyaan dan siswa diberikan kesempatan untuk menjawab pertanyaan di kertas yang sudah di berikan secara bergantian. (6) Evaluasi dan Penutup.

\section{METODE PENELITIAN}

Jenis penelitiaan ini adalah penelitian ekfost facto. Tetapi artikel ini tidak melakukan penelitian hanya saja mengambil hasil penelitian dari orang lain. Dimana penelitian ini mencari 10 penelitian yang menggunakan model pembelajaran Snowball Throwing. Artikel yang menyatakan bahwa dengan menggunakan model pembelajaran Snowball Throwing ini ada di Undiksha, Unnes, UNM Penulisan karya ilmiah ini menggunakan metaanalisis dengan menggunakaan beberapa hasil penelitian. Beberapa hasil penelitian ini terdapat pengumpulan data dan penelitian dari berberapa sumber lain. Dari beberapa jurnal hasil penelitian mencari di google sholaria dan google cendekia. Dengan kata kunci pengumpulan data yang digunakan yaitu hasil belajar dan snowball throwing. Dari beberapa sumber yang dicari, memilih sumber yang sesuai dengan pembahasan yang akan disampaikan penulis dalam karya ilmiah ini. Dalam sumber yang dipilih akan didapatkan termuat dalam bentuk \% untuk mengukur besar pengaruh penggunaan model pembelajaran Snowball Throwing. Kemudian dari beberapa hasil penelitian yang ada di tabel-tabel dapat ditarik kesimpulan berhasil atau tidak menggunakan Snowball Throwing ini dapat meningkatkan hasil belajar siswa.

\section{HASIL DAN PEMBAHASAN}

\begin{tabular}{lllcl}
\hline No & Peneliti & \multicolumn{1}{c}{ Judul/Tema } & Tahun & Hasil \\
\hline 1. & Abd & Penerapan Metode & 2017 & Pada pertemuan I aktivitas siswa yang \\
& Rahman & Snowball Throwing & & diperoleh adalah 50,00 dan masuk \\
& Untuk & & dalam kategori kurang dan pada \\
& Meningkatkan & pertemuan kedua aktivitas siswa \\
& Hasil Belajar IPS & meningkat menjadi 60,00\% dan sudah \\
& Siswa Kelas V & masuk dalam kategori Cukup. \\
& Pada SDN No. 1 & Pelaksanaan pada siklus II \\
& Pantolobete & memperbaiki kelemahan yang terjadi \\
& & pada siklus pertama sehingga \\
& & meminimalisir kesalahan yang \\
& & dilakukanoleh guru maupun oleh siswa \\
& & sehingga nilai yang diperoleh pada \\
& & pertemuan pertama untuk aktivitas \\
& & siswa 75,00 dan pada pertemuan kedua \\
\hline
\end{tabular}


2. Akhiriyah, Penerapan Model D. Y.

Pembelajaran

Snowball Throwing

Untuk

Meningkatkan

Kualitas

Pembelajaran Ips
3. Md. Puspa Pengaruh Model

Dewi, I Pembelajaran

Kt. $\quad$ Snowball Throwing

Adnyana Terhadap Hasil

Putra, I Belajar Ipa Siswa

Gst. A. Kelas V Sd Di

Oka Gugus Sri Kandi

Negara Kecamatan

Denpasar Timur

4. Ni Putu Pengaruh Model

Eka Pembelajaran

Restiti Snowball Throwing

Aniati, Berbasis

Dewa Keterampilan

Nyoman Proses terhadap

Sudana, I Hasil Belajar IPA

Komang Siswa Kelas V

Sudarma memperoleh skor $90,00 \%$ dari hasil ini

menunjukan bahwa sudah ada peningkatan yang signifikan dari siklus I ke siklus II dari setiap pertemuan dan hasil belajar yang diperoleh yaitu untuk ketuntasan klasikal yang diperoleh adalah sebesar $92,90 \%$ dan daya serap klasikal $85,71 \%$

2011 Snowball Throwing dapat meningkatkan aktivitas guru dalam pembelajaran IPS. Hal ini ditunjukan dengan meningkatnya aktivitas guru pada setiap siklus. Hal ini dapat dilihat dari hasil pengamatan aktivitas guru pada siklus I adalah 2,5 sedangkan pada siklus II 3,0 dan pada siklus III adalah 3,4 Yang masuk dalam kategori sangat baik. Meningkatkan aktivitas siswa dalam pembelajaran IPS. Hal ini dapat dilihat dari hasil pengamatan aktivitas siswa pada siklus I adalah 3,0 sedangkan pada siklus II adalah 3,53 dan siklus III adalah 3,56 yang termasuk katergori sangat baik. Dapat meningkan hasil belajar IPS. Hal ini dapat dilihat dari hasil belajar IPS pada siklus I adalah $60 \%$, pada siklus II adalah $73,9 \%$ dan pada siklus III adalah $84,7 \%$.

2013 Hasil analisis penelitian yang menunjukkan t-hitung $=2,562>$ t-tabel $=2,000$ dan didukung oleh perbedaan skor rata - rata yang diperoleh antara siswa yang mendapat treatment model pembelajaran Snowball Throwing yaitu $X=83,50>X$ 71,20 pembelajaran konvesional. Dapat disimpulkan dengan adanya pengaruh penerapan model pembelajaran Snowball Throwing terhadap hasil belajar IPA siswa kelas V SD di Gugus Sri Kandi Kecamatan Denpasar Timur 2012/2013 Dari rata-rata (X) hitung dapat diketahui terdapat dua kelompok yaitu kelompok eksperimen mempunyai rata-rata $18,03 \%$ sedangkan kelompok kontrol memiliki rata-rata 14,64 . Hal ini berarti, X eksperimen > X kontrol. Berdasarkan hasil temuan tersebut, dapat disimpulkan bahwa penggunaan model pembelajaran Snowball 


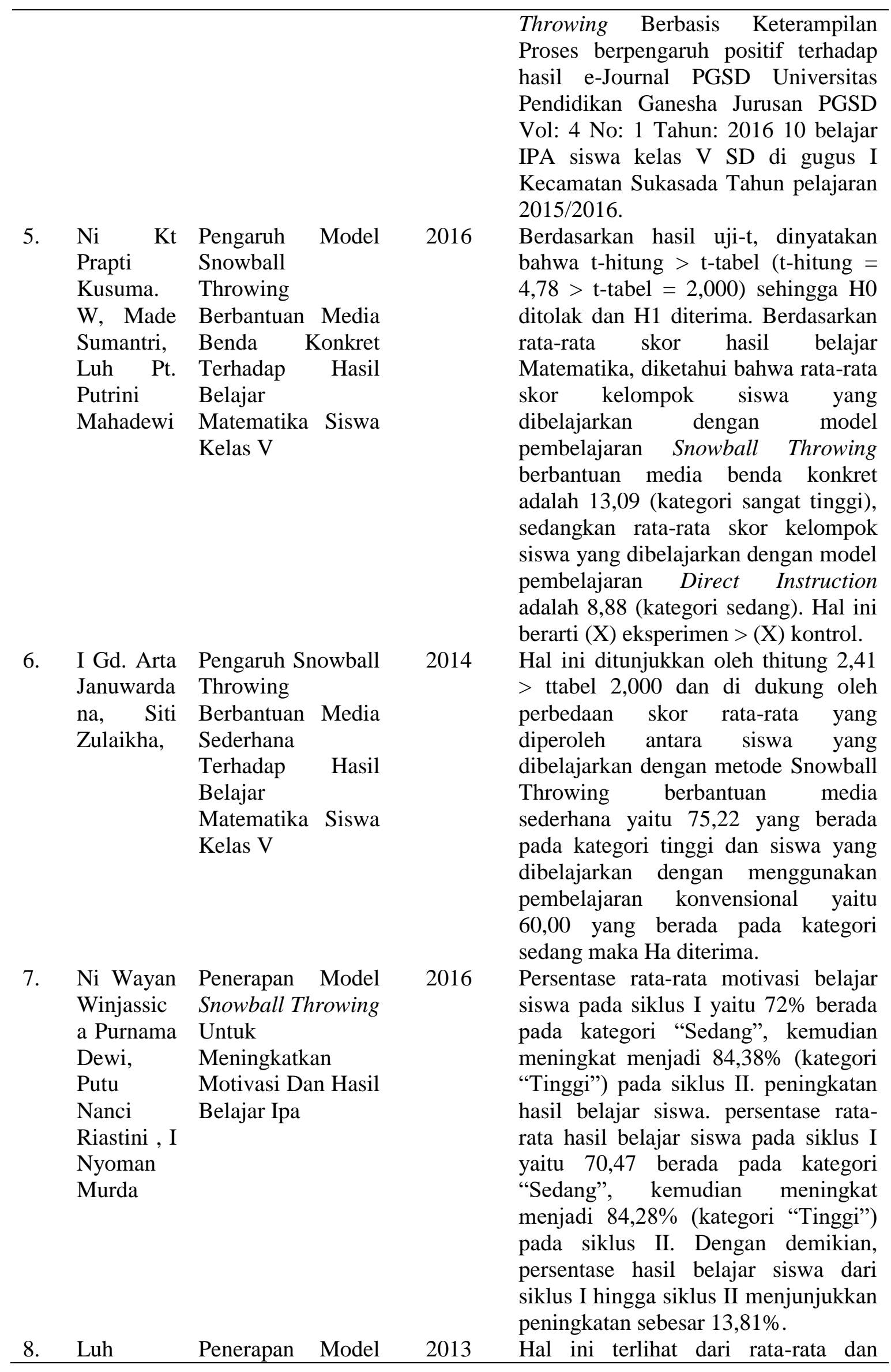




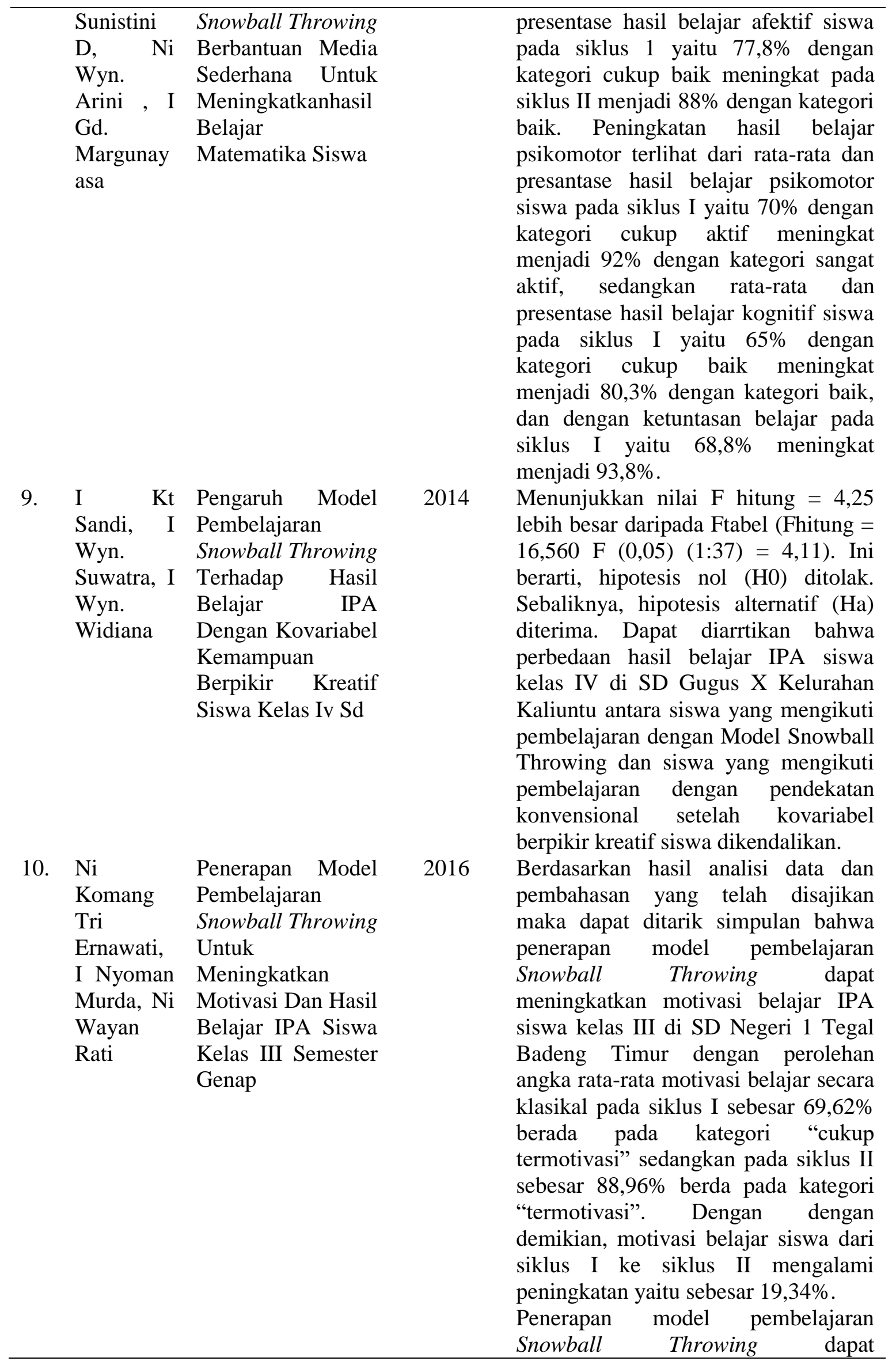


meningkatkan hasil belajar IPA siswa kelas III di SD Negeri 1 Tegal Badeng Timur dengan perolehan angka ratarata hasil belajar secara klasikal pada siklus I sebesar $67,03 \%$ berada pada kategori "sedang", sedangkan pada siklus II sebesar $81,11 \%$ berada pada kategori "tinggi". Dengan demikian hasil belajar siswa dari siklus I ke siklus II mengalami peningatan yaitu sebesar $14,08 \%$.

\section{SIMPULAN DAN SARAN}

Dari bahasan yang diatas dapat disimpulkan dalam kurikulu 2013 sebernarnya masih belum menerapkan apa yang dibuat oleh pemerintah, masih banyak yang menggunakan KTSP, sehingga sekolah tersebut ketinggalan zaman. Dalam penggunaan kurikulum 2013 masih kurang maksimal. dengan begitu pemerintah melakukan perbaikan dalam kuikulum 2013 sehingga sekolah dapat memiliki kesempatan untuk melakukan kurikulum 2013. Dengan adanya kurikulum 2013 guru harus kreatif dalam memilih banyak modelmodel pembelajaran yang sesuai dengan karakteristik siswanya. Dengan demikan dengan menggunaka model pembelajaran Snowball Throwing ada sepuluh penelitian menyatakan bahwa berhasil dalam meningkatkan hasil belajara siswa walaupun itu harus bertahap secara perlahan.

Berdasarkan beberapa penelitian memiliki tujuan untuk meningkatkan hasil belajar siswa berbagai mata pelajaran seperti IPS, PPkn, IPA, Matematika dengan menggunakan model pembelajaran Snowball Throwing. Dari beberapa sepuluh hasil penelitian yang tercantum di bagian pembahasan guru berhasil meningkatkan hasil belajar siswa tetapi harus bertahap, sehingga dapat memperoleh hasil yang memuaskan. Dengan demikian guru dapat menggunakan model pembelajaran Snowball Throwing.

\section{DAFTAR RUJUKAN}

Akhiriyah, D. Y. (2011). Penerapan Model Pembelajaran Snowball Throwing Untuk Meningkatkan Kualitas
Pembelajaran IPS Pada Siswa Kelas V Sdn Kalibanteng Kidul 01 Kota Semarang (Aplicating Snowball Throwing Model For Improving The Social Intructional At Fifth, Sdn Kalibanteng Ki. Jurnal Kreatif: Jurnal Kependidikan Dasar, 1(2).

Aniati, N. P. E. R., Sudana, D. N., \& Sudarma, I. K. (2016). Pengaruh Model Pembelajaran Snowball Throwing Berbasis Keterampilan Proses Terhadap Hasil Belajar Ipa Siswa Kelas V. Mimbar Pgsd Undiksha, 4(1).

Dewi, M. P., Putra, I. K. A., \& Negara, I. G. A. O. (2013). Pengaruh Model Pembelajaran Snowball Throwing Terhadap Hasil Belajar Ipa Siswa Kelas V Sd Di Gugus Sri Kandi Kecamatan Denpasar Timur. Mimbar Pgsd Undiksha, 1(1).

Dewi, N. W. W. P., Riastini, P. N., \& Murda, I. N. (2016). Penerapan Model Snowball Throwing Berbantuan Satua Bali Untuk Meningkatkan Motivasi Dan Hasil Belajar Ipa. Mimbar Pgsd Undiksha, 4(1).

Ernawati, N. K. T., Murda, I. N., \& Rati, N. W. (2016). Penerapan Model Pembelajran Snowball Throwing Untuk Meningkatkan Motivasi Dan Hasil Belajar Ipa Siswa Kelas Iii Semester Genap Sdn 1 Tegal Badeng Timur Kecamatan Negara Kabupaten Jembrana Tahun Pelajaran 2015/2016. Mimbar Pgsd Undiksha, 4(1). 
Januwardana, I. G. A., Zulaikha, S., \& Made Putra, M. P. (2014). Pengaruh Metode Snowball Throwing Berbantuan Media Sederhana Terhadap Hasil Belajar Matematika Siswa Kelas V Sd Gugus 1 Kuta Badung. Mimbar Pgsd Undiksha, 2(1).

Luh Sunistini, D., Arini, N. W., \& Margunayasa, I. G. (2013). Penerapan Model Snowball Throwing Berbantuan Media Sederhana Untuk Meningkatkanhasil Belajar Matematika Siswa Di Sd No 1 Petandakan. Mimbar Pgsd Undiksha, 1(1).

Rahman, A. (2013). Penerapan Metode Snowball Throwing Untuk Meningkatkan Hasil Belajar Ips Siswa Kelas V Pada Sdn No. 1 Pantolobete. Jurnal Kreatif Tadulako Online, 5(4).

Sandi, I. K., Suwatra, I. I. W., \& Widiana, I. W. (2014). Pengaruh Model Pembelajaran Snowball Throwing Terhadap Hasil Belajar Ipa Dengan Kovariabel Kemampuan Berpikir Kreatif Siswa Kelas Iv Sd. Mimbar Pgsd Undiksha, 2(1).

Wardani, N. K. P. K., Made Sumantri, M. P., \& Mahadewi, L. P. P. (2016). Pengaruh Model Snowball Throwing Berbantuan Media Benda Konkret Terhadap Hasil Belajar Matematika Siswa Kelas V. Mimbar Pgsd Undiksha, 4(1). 